\title{
DEMAND-SIDE MANAGEMENT FOR ENERGY IN THE REGION
}

The article deals with a promising approach to solving the problem of investment in the regional electric power industry - the application of demand-side management, the essence of which lies in proactive interaction of energy companies with customers, based on the balance of economic interests. The features of the concept and its tools are revealed, positive results of its implementation for energy market players and the region are shown, and examples of demand-side management programs are given. Institutional and mental barriers to effective implementation of demand-side management tools in power generation are analyzed. The article also proposes algorithms for implementing demand-side management programs in the region, and a mix of motivational activities that combines methods of administrative enforcement and economic stimulus for energy companies and consumers of energy and power, as well as guidelines on project funding and effectiveness evaluation.

Keywords: demand-side management for energy, energy efficiency, load management, demonstration experiment, the investment mechanism, innovations, market economy

The Energy Strategy of Russia through to 2030 proclaims a need for a transition from the raw materials model of power generation to a smart one that is based on breakthrough technological innovations. The document points out that achieving the goal requires investing some 2,500 billion dollars in the energy sector in the next 20 years, including 600 to 900 billion dollars in power generation. The primary sources of finance include Russian and foreign companies' own funds, loans, funds raised from additional share issues and government subsidies [5], i. e., standard investment mechanisms.

Meanwhile, a number of advanced solutions to the problem of investment in the electrical power industry has been used abroad but has not been given due consideration in Russia. The most effective one is the application of demand-side management (DSM) - proactive methods of economic interaction between energy suppliers and 


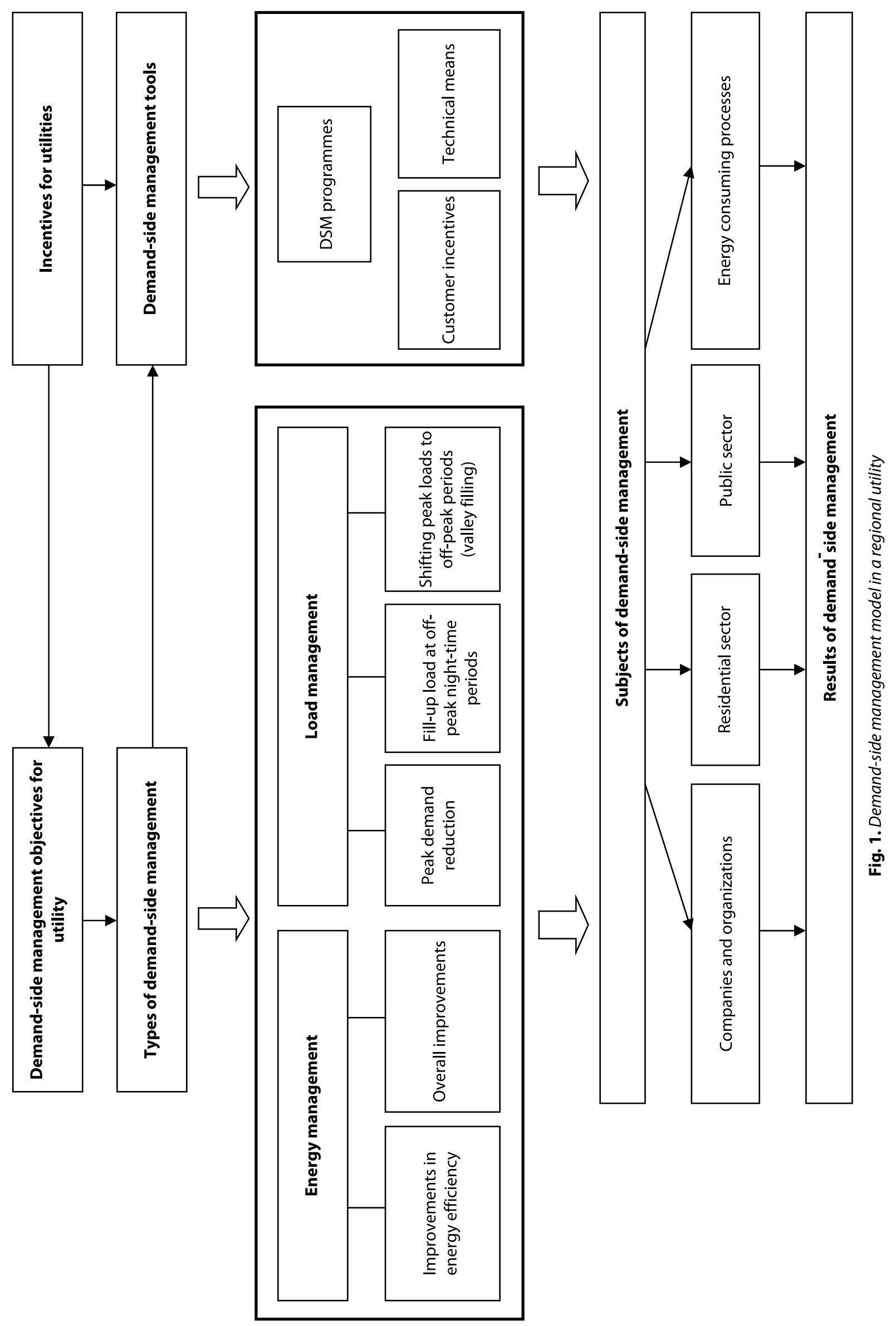


Estimates for meeting additional demand

\begin{tabular}{|l|c|c|c|}
\hline \multicolumn{1}{|c|}{ Indicator } & Reference conditions & Generation & Energy conservation \\
\hline Production costs, million roubles & 1800 & 1803 & 1800 \\
\hline Fixed assets, million roubles & 4500 & 4650 & 4530 \\
\hline Profit margin (generation), \% & 10 & 10 & - \\
\hline Profit margin (energy conservation), \% & - & - & 35 \\
\hline Profit (gross), million roubles & 450 & 465 & 460.5 \\
\hline Sales (1+5), million roubles & 2250 & 2268 & 2260.5 \\
\hline Output, million kWh & 750 & 752.5 & 750 \\
\hline Electricity tariff (6:7), rouble/(kWh) & 3 & 3.014 & 3.014 \\
\hline Investment, million roubles & - & 150 & 30 \\
\hline Profit minus investment (5-9), million roubles & - & 315 & 430.5 \\
\hline
\end{tabular}

consumers that ensure mutually beneficial modification of the quantity and patterns of electricity consumption. The concept of demand-side management emerged in the early 1970s in the USA and has been successfully adopted in over 30 countries. Essentially, DSM means systematic utility activities to influence the quantity, timing and patterns of electricity use in a service area [2].

There are two interconnected forms of demand side management: energy control and energy management (fig. 1). Both of them are applicable for Russian regions, but they can receive different priority in different grids. An additional aspect is that DSM programmes increase the investment attractiveness of the area's energy sector as they are aimed at improving energy and environmental effectiveness as well as encouraging the growth of the region's economy as a whole [4].

The effectiveness of demand-side management is determined by the end results that are different for utilities, consumers and the region as a whole.

1. Utility:

- reducing the cost of construction and operation of generation and transmission capacity;

- market expansion and increasing the longterm stability of financial performance;

- creating a favorable image of the company in the region.

2. Electricity consumers:

- increased reliability and quality of electricity supply; tariffs;

- lower and stable electricity and heating

- lower energy intensity of products and services and expanded electrification at comparably lower costs.

3. Region (long-term societal interests):

- more sustainable energy supply for economic growth;

- higher level of energy self-sufficiency;
- socio-economic benefits of electrification and district heating;

- environmental and eco-economic benefits and improved investment climate [3].

A classical example of a DSM policy is encouraging a regional utility to make investments in energy efficiency [1]. Let's assume that demand for an additional 2.5 million $\mathrm{kWh}$ has emerged in a region that is served by a utility with an annual output of 750 million $\mathrm{kWh}$. The extra demand could be satisfied either by building additional generation capacity at a cost of 150 million roubles, or by implementing an energy efficiency programme worth 30 million roubles. In the second case, the freed-up capacity is used to provide for the additional demand and electricity output does not increase. Furthermore, regulators allow a $10 \%$ profit margin in electricity tariffs for generation and a $35 \%$ margin for energy conservation. Investments in generation capacity or energy efficiency are reckoned as capital funds and are included in the base rate. Estimates for both options of meeting the additional demand are reported in Table 1 and show obvious benefits of implementing the DSM programme.

In a market economy that is based on commercial interests, electricity consumers who are challenged by competitors to reduce their production costs, as well as by electricity suppliers seeking to cut the growing cost of building a new generation and transmission capacity could initiate DSM programmes.

Effectively, three approaches are currently in use for managing demand for electricity and capacity. The first one is customer-initiated DSM. The second approach is compulsory direct load control during peak usage times that is performed by the grid operator (operations control units) to balance the system load and maintain the electricity parameters in the situation of capacity shortages. Finally, demand-side management through 
cooperation between the utility and customers on voluntary and mutually beneficial terms.

The third of the above mentioned policies appears to be the most effective, especially under the market model of the industry as it provides for a wider range of ways for improving energy efficiency, finds application on a regular basis and, last but not the least, is based on economic interests of power supply partners. At the same time, this does not deny the importance and sometimes the necessity to carry out customer-initiated and direct peak demand management methods, with the latter ones usually employed temporarily and only during emergency situations.

It may seem that Russia has favourable conditions for adopting demand side management based on interactions between a utility company and its customers and a balance of their interests. It is, above all, a huge potential for energy conservation and improved energy efficiency on one hand, and the problem of investment in generating and transmission capacity on the other. At the same time, despite the slow economic growth, the industry is faced with a pressing need for an overhaul of its worn-out and obsolete production facilities.

Nevertheless, there are a number of barriers hindering the progress of this highly promising demand-side management approach, both institutional and purely mental ones.

Let's start with power consumers who are the targets of demand-side management. It is known that despite having a lot of room for energy efficiency improvement, the overwhelming majority of manufacturing companies are fairly indifferent to their energy expenditures. A low level of competition in manufacturing has been typically cited as the key reason for this, which is of course true, especially coupled with a relatively low share of energy costs in production costs for many industries. It is no secret, though that defense companies exporting their products abroad enjoy discounts on electricity prices, mainly through cross-subsidies from other "unqualified" consumers".

But there are other equally important reasons. Specifically, many companies do not have energy managers who would be skilled enough to give a correct assessment of the effectiveness of energy efficiency innovations and, more importantly, of technical, economic and production impact of modifying their daily load curves, including the need for extra spending. Additionally, the management of a factory often avoids disclosing its reserves to the energy supplier that needs to conduct an energy audit as part of developing its DSM programme. The unspoken rule is that the less energy efficient you are, the easier it is to secure a lower electricity tariff while it is always easier to "settle things" with a specialist energy audit company. Finally, there is a traditional distrust of any activities by the energy supplier, especially when it offers a new, difficult-to-understand service.

Let's now move on to utility companies, both integrated and grid ones. Many of them do not have a clear understanding of how real money can be invested in the customer while losing cashflow. At the same time, many energy managers as "virtual" view such benefits as being able to postpone generation infrastructure investments or even to avoid them. The need to offer rebates and compensation that would have to be adjusted for inflation regularly does not induce enthusiasm. That's why these mechanisms that have proved rather successful abroad look extremely doubtful to Russian energy managers.

The above-mentioned facts can partly explain the stance that has been taken by the Russian Energy Ministry on the issue of promoting demand-side management in the country.

There are also organizational problems within utility companies. In order to design DSM programmes, interact with customers and suppliers of energy efficient equipment, it is necessary to reengineer the entire marketing operation of the company, which is a huge task that would entail a review of many processes involving a lot of staff and, eventually extra expenses.

Other countries' experience show that managing demand from existing customers enables utility companies to serve their new clients at lower tariffs. But companies have to be highly motivated to fight for every single customer and to seek to improve the quality of service. This is definitely not the case in Russia where it might take a customer several months to get connected to a regional grid and where a distribution network operator might turn down a connection application, citing "technical infeasibility". Institutional issues are also worth mentioning. There is no doubt that the reorganization of the energy sector, the unbundling of vertically integrated companies seriously aggravated conditions for demand-side management and shifted the focus to the regional grid companies that usually do not have enough potential for these activities. In this connection, we would like to point that in a general case peak loads in the generation system do not coincide with those in the distribution network. That is why it might be appropriate to get the grid operator involved in determining the level and timing of the peak demand. 


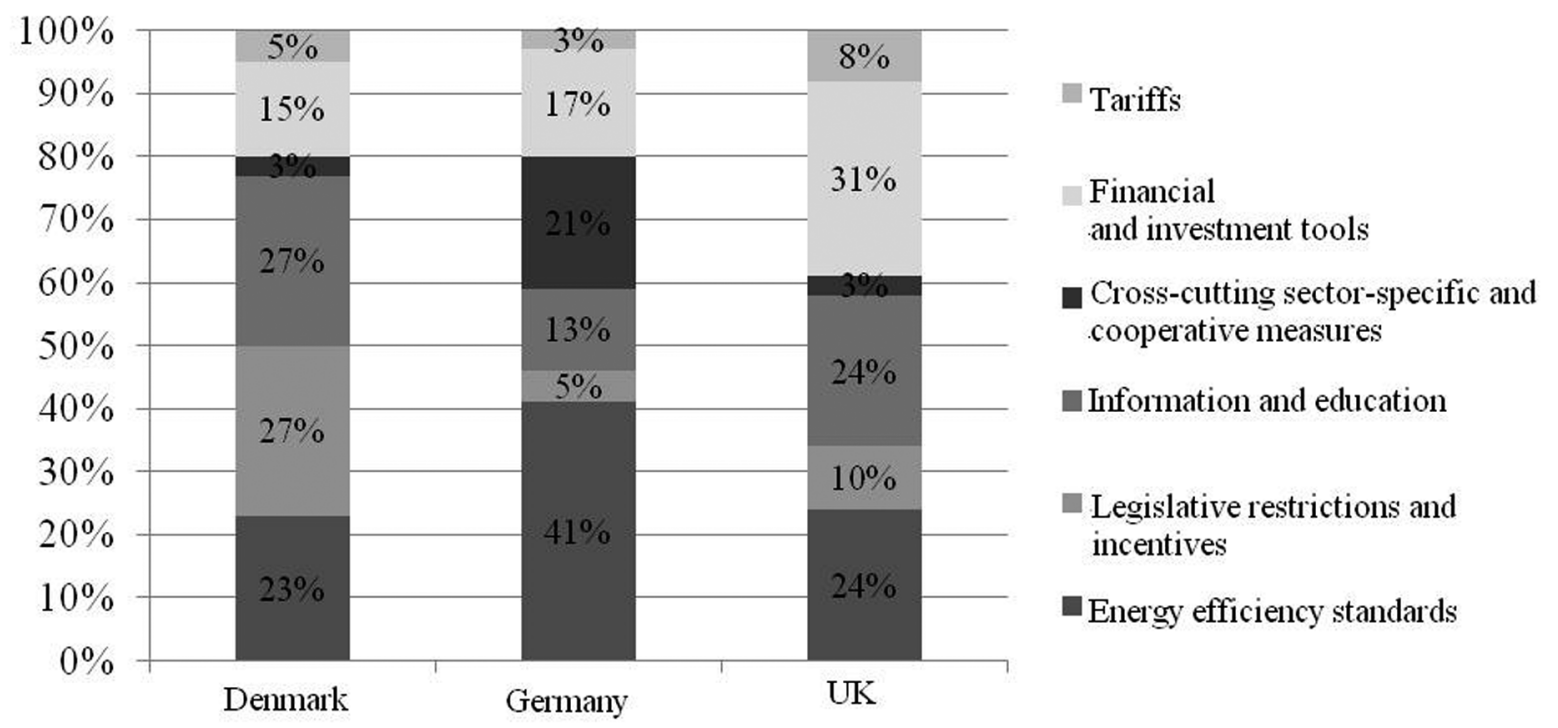

Fig. 2. Types of incentives for actors involved in DSM policies

It is necessary to set clear and unequivocal standards for connecting new users to the grid and specify exceptional ("force majeure") situations when the connection is impossible at the moment; the same refers to regulating the connection fee and transmission tariffs.

In order to overcome the established traditions and mentality of energy managers, an algorithm for demand side management in a region is proposed. It includes a set of compulsory regulatory measures aimed to motivating utility companies. The algorithm consists of the following steps [2].

1) Select promising end-user companies on an agreement with their energy managers;

2) Conduct an energy audit at the selected facility (with the involvement of specialist organizations);

3) Design a DSM programme for a target period (with preliminary effectiveness assessment);

4) Estimate costs (within the programme budget);

5) Select suppliers of efficient equipment and devices;

6) Sign contracts with users and suppliers of energy efficient equipment;

7) Monitor the programme implementation (including necessary adjustments);

8) Analyze the results of the programme implementation during the reporting period;

9) Spread financial benefits of implementing the DSM programme among consumers and energy companies in the region;

10) Work out proposals for extending the duration of the programme and expanding the number of the companies enrolled across the region [2].
While following the suggested series of steps, it is worthwhile to design and carry out a model demonstration DSM experiment in one (or several) of the regions of the country and to spread its results among utilities and customers (by employing modern information and advertising means). Demonstration demand-side management programmes have been widely acclaimed abroad, both in developed countries (USA, Germany, France) and in developing countries (China, India, Thailand, Vietnam, Singapore, South Korea) that have gone through the restructuring of their energy systems and are now facing similar organizational sector-specific barriers. Demonstration projects are a starting point for adopting the concept of demand-side management and are usually associated with inexpensive and quick actions.

The results and conclusions of the experiment should provide a basis for creating an industrywide legal framework that would regulate the activities of all actors involved in regional DSM programmes, stipulate necessary institutional transformations and contain a relevant package of regulatory measures and economic instruments for utilities as well as for end users ${ }^{1}$. Here is an example of a set of regulatory and economic measures.

1. Utilities are legally required to design and implement DSM programmes in cooperation with customers. A clause to this effect should be incorporated into federal and regional energy legislation.

2. A utility's request for a tariff increase exceeding inflation must only be considered by in-

\footnotetext{
${ }^{1}$ For the utility, it would mean an obligation to design and implement DSM programmes, enrolling qualifying customers as it shall not turn down new clients even in the case of capacity shortage.
} 
Cost effectiveness of demand side programmes

\begin{tabular}{|c|c|c|}
\hline Measure & Benefits & Costs \\
\hline $\begin{array}{l}\text { PCT (Participant Cost Test) } \\
\text { - from the perspective of the } \\
\text { customer }\end{array}$ & $\begin{array}{l}\text { Incentive payments } \\
\text { Bill savings } \\
\text { Tax rebates or incentives }\end{array}$ & $\begin{array}{l}\text { Incremental equipment and installation } \\
\text { costs }\end{array}$ \\
\hline $\begin{array}{l}\text { PACT (Programm Administrator } \\
\text { Cost Test) - from the } \\
\text { perspective of government } \\
\text { agencies and third party entities }\end{array}$ & $\begin{array}{l}\text { Capacity-related costs avoided thanks to } \\
\text { programme (deferred investment) }\end{array}$ & $\begin{array}{l}\text { Overhead costs } \\
\text { Utility incentive costs } \\
\text { Installation costs }\end{array}$ \\
\hline $\begin{array}{l}\text { RIM (Ratepayer Impact } \\
\text { Measure) - impact of energy } \\
\text { efficiency programs on } \\
\text { ratepayers overall }\end{array}$ & $\begin{array}{l}\text { Capacity-related costs avoided thanks to } \\
\text { programme (deferred investment) }\end{array}$ & $\begin{array}{l}\text { Program overhead costs } \\
\text { Utility incentive costs } \\
\text { Installation costs } \\
\text { Lost revenue due to reduced energy bills }\end{array}$ \\
\hline $\begin{array}{l}\text { TRC (Total Resource Cost Test) } \\
\text { - from the perspective of all } \\
\text { utility customers } \\
\text { (participants and non- } \\
\text { participants) in the utility service } \\
\text { territory }\end{array}$ & $\begin{array}{l}\text { Capacity-related costs avoided thanks to } \\
\text { programme (deferred investment) } \\
\text { Additional resource savings (e.g., gas } \\
\text { and water) } \\
\text { Monetized environmental and non-energy } \\
\text { benefits } \\
\text { Applicable tax credits }\end{array}$ & $\begin{array}{l}\text { Overhead costs } \\
\text { Installation costs } \\
\text { Incremental measure costs (whether } \\
\text { paid by the customer or the utility) }\end{array}$ \\
\hline $\begin{array}{l}\text { SCT (Societal Cost Test) - costs } \\
\text { and benefits to all in the service } \\
\text { territory, region, or nation as a } \\
\text { whole }\end{array}$ & $\begin{array}{l}\text { Capacity-related costs avoided thanks to } \\
\text { programme (deferred investment) } \\
\text { Additional resource savings (e. g., gas } \\
\text { and water) } \\
\text { Non-monetized benefits such as cleaner air }\end{array}$ & $\begin{array}{l}\text { Overhead costs } \\
\text { Installation costs } \\
\text { Incremental measure costs (whether } \\
\text { paid by the customer or the utility) }\end{array}$ \\
\hline
\end{tabular}

dustry regulators if a customer-approved DSM programme is available. If the programme is not rolled out within a stipulated period, the tariff revision request will be automatically blocked.

3. A license for building generation capacity in new locations is issued to a utility on a condition that a certain share (e. g., 30 per cent) of investment in new construction must be used concurrently towards energy efficiency. An exception could be made for renewable energy projects and highly efficient combined cycle power plants.

4. On an agreement with costumers, a utility gets the right to charge special tariffs that encourage efficient energy use and sustainable energy consumption patterns. The utility is prohibited from shifting the costs of energy supply to other ratepayers.

5. Regulatory agencies should establish a higher rate of return on the capital that a utility invests in energy conservation.

6. Energy producers should be allowed to deduct a share of their expenses on designing a DSM programme from their corporate tax bill.

7. In case the utility's investments in the consumer sector account for over 50 per cent of its total investments during a reporting period, it is advisable either to deduct these costs from the corporate tax bill, or to apply a reduced tax rate.

At the same time, a wide scope of incentives (a scale of tariffs, discounts on energy efficient equipment, energy conservation education) should be employed for power and capacity con- sumers. Key incentives that are currently in use in Denmark, Germany and Great Britain are illustrated by Figure 2 [6].

To evaluate the effectiveness of demand-side management programmes, an internationally recognized methodology could be used that is based on comparing costs and benefits from the perspective of different actors (table 2).

Speaking about funding for DSM programmes, it appears worthwhile to set up regional energy efficiency (energy conservation) funds that would accumulate financial resources of wholesale and territorial energy producers, as well as funding provided by the Federal Grid Company. To do this, appropriate companies should be required to make allocations from their net income (depreciation plus profit) to the funds. Grid companies implementing DSM programmes would be entitled to use resources from the regional funds in a prescribed mode to expand their investment opportunities and to replenish programme budgets.

In this case, an industry-independent state organization would be put in charge of operating the regional energy efficiency fund, performing administrative and distribution functions such as: fundraising ${ }^{1}$; spending control; spreading the economic benefits of programmes among investors; returning unused financial resources to con-

\footnotetext{
${ }^{1}$ Energy efficiency funds should also accumulate receipts from fines paid by utilities and consumers who avoid participation in DSM programmes.
} 
tributors. The operators of energy efficiency funds could also provide power generation companies with information regarding DSM programmes that are being designed and delivered by electricity distributors.

We would like to emphasize that the successful overcoming of mental barriers and creation of an acceptable institutional environment directly depends on whether the Russian government and, specifically, the Russian Energy Ministry take a forward-looking position on this unique energy and economic innovation and recognize its significance for effective power supply of the national economy and, consequently, for the country's economic growth.
In conclusion, it should be noted that the effects of employing demand-side management tools can only be realized in five to ten years since the start of pilot projects, provided that there is necessary legislation in place, support of financial institutions is available and developed energy services markets exist. That is why it is commonly believed that the concept of demand-side management should be incorporated into the framework of the power sector reform. Otherwise, (as it happened in China, for example, and as it is now in Russia) a large number of above-mentioned barriers will get in the way of implementing demand-side management mechanisms.

\section{References}

1. Gitelman L. D., Ratnikov B. E. (2006). Energeticheskiy biznes [Energy Business]. Moscow, Delo [Publishing house «Delo»].

2. Gitelman L.D., Ratnikov B. E., Kozhevnikov M. V. (2012). Upravleniye sprosom na elektroenergiyu: zarubezhnyy opyt i adaptatsiya $\mathrm{k}$ rossiyskim usloviyam [Demand-side management: international experience and adaptation to Russian conditions]. Effektivnoe antikrizisnoye upravleniye [Effective Crisis Management], 6, 61-65.

3. Kuklin A. A., Belik I.S. (2009). Vliyaniye ekologo-ekonomicheskoy bezopasnosti na investitsionnuyu privlekatelnost regiona [The influence of environmental and economic security on the investment attractiveness of the region]. Ekonomika regiona [Economy of Region], 4, 155-158.

4. Myzin A. L., Mezentsev P. E., Pyhov P. A., Denisova O. A. (2007). Sravnitelnaya otsenka energoinvestitsionnoy privlekatelnosti regionov: metod i aprobatsiya [Comparative assessment of energy investment attractiveness of regions: method and validation]. Ekonomika regiona [Economy of Region], 4, 207-220.

5. Energeticheskaya strategiya Rossii 2030 [Energy Strategy of Russia 2030]. Available at: http://minenergo.gov.ru/aboutminen/ energostrategy/

6. Haney A.B., Jamasb T., Platchkov L.M., Pollitt M.G. Demand-side Management Strategies and the Residential Sector: Lessons from International Experience. Available at:www.eprg.group.cam.ac.uk

7. Understanding Cost-Effectiveness of Energy Efficiency Programs: Best Practices, Technical Methods, and Emerging Issues for Policy-Makers. Available at: http://www.epa.gov/cleanenergy/documents/suca/cost-effectiveness.pdf

\section{Information about the authors}

Gitelman Lazar Davidovich (Yekaterinburg, Russia) - Ph.D. in Economics, Professor, Head of the Chair for Energy and Industrial Management Systems, Ural Federal University named after the first President of Russia B.N. Yeltsin (620002, Yekaterinburg, Mira str. 19, e-mail: ldgitelman@gmail.com).

Ratnikov Boris Evgenyevich (Yekaterinburg, Russia) - Ph.D. in Economics, Professor of the Chair for Energy and Industrial Management Systems, Ural Federal University named after the first President of Russia B.N. Yeltsin (620002, Yekaterinburg, Mira str. 19).

Kozhevnikov Mikhail Viktorovich (Yekaterinburg, Russia) - postgraduate student of the Chair for Energy and Industrial Management Systems, Ural Federal University named after the first President of Russia B.N. Yeltsin (620002, Yekaterinburg, Mira str. 19, e-mail: np.fre@mail.ru). 